\title{
The Influence of Patients' Knowledge of Hypertension on the Control of Their Blood Pressure - Qualitative Study
}

\author{
Tinde I. Halgato ${ }^{1}$, Dora K. Kaloci ${ }^{1}$, Roland N. Grujić ${ }^{1}$, Sabolč J. Mora ${ }^{1}$, \\ Ana D. Tomas², Milica M. Paut Kusturica², Olga J. Horvat ${ }^{2}$ \\ ${ }^{1}$ Health Center "Dr Janoš Hadži” Bačka Topola, Serbia \\ ${ }^{2}$ Department of Pharmacology and Toxicology, Faculty of Medicine Novi Sad, University of \\ Novi Sad, Novi Sad, Serbia
}

\section{SUMMARY}

Introduction: Hypertension is a significant risk factor for stroke, myocardial infarction, and heart failure. Maintaining adequate blood pressure helps preventing cardiovascular complications.

Aim: The aim of this study was to investigate the knowledge about hypertension and associated factors in controlling high blood pressure among hypertensive outpatients in the municipality of Bačka Topola, Republic of Serbia.

Methods: The outpatients who visited their doctors and agreed to fill out an anonymous questionnaire were included in the survey conducted in March 2019 at the Primary Health Care Center of the municipality of Bačka Topola. The questions were related to the sociodemographic characteristics and medication-associated factors of significance for assessment of the outpatients' knowledge about antihypertensive drugs.

Results: The mean age of patients was $62.9 \pm 10.7$ years. Most frequently prescribed antihypertensive drugs were ACE inhibitors $(80.8 \%)$ followed by beta blockers $(46.8 \%)$, calcium channel blockers $(22.6 \%)$ and diuretics $(21 \%)$, fixed dose antihypertensive drugs were used by $4.8 \%$ patients. Majority of adequate knowledge participants had well controlled blood pressure $(91.4 \%)$, while only $37.1 \%$ of average knowledge participants had well controlled blood pressure. The other factors related to poor blood pressure control and lower level of knowledge about hypertension were older age, female gender, lower level of education, less frequent visits to the GP, patients with more than one antihypertensive drug, patients with longer duration of hypertension treatment and patients who were not paying copayment for their antihypertensive drugs.

Conclusions: The results of our study indicate that the patients' knowledge about hypertension and associated factors regarding the treatment of hypertension play an important role in maintaining blood pressure at the safe level. Therefore, educational campaigns are the key factors for the quality and satisfactory knowledge about use of antihypertensive drugs and management of hypertension.

Keywords: antihypertensive therapy, patients, knowledge about hypertension, antihypertensive drugs 


\section{INTRODUCTION}

Hypertension and its complications are a leading cause of morbidity and mortality in the Republic of Serbia. According to the European Hypertension Society and the European Society of Cardiology, the prevalence of hypertension appeared to be around $30-45 \%$ of the general European population [1]. According to a survey conducted in 2006 in Serbia, 46.5\% of the population over the age of 20 had high blood pressure or were taking antihypertensive drugs, while a 2013 study showed even a slight increase in the incidence of high blood pressure (47.5\%)[2,3]. According to the Institute of Public Health, 52.012 people in the Republic of Serbia died of cardiovascular diseases (CVD) in 2016, which makes a half $(51.7 \%$ ) of all deaths [4]. In Vojvodina 13.780 people died from CVD in 2015, and 50.6\% of all causes of death were related to CVD [5].

The treatment of hypertension is based on non-pharmacological and pharmacological options. Numerous clinical studies have shown that lifestyle changes, adequate weight, smoking cessation, reduced salt and alcohol intake, and regular physical activity help to maintain blood pressure at an adequate level. Antihypertensive drugs effectively reduce or delay cardiovascular complications associated with hypertension, reducing the incidence of myocardial infarction and stroke [6]. Drugs for the treatment of cardiovascular disease (ATC classification: Group C) accounted for $39.82 \%$ of all drugs in Serbia in 2010. Despite neither of the main types of antihypertensives had been favored in clinical guidelines, angiotensin-converting-enzyme inhibitors (ACE inhibitors) were the most commonly used drug group [7].

Despite the established evidence of benefits of controlling raised blood pressure, the development of several guidelines on the detection and management of hypertension, and a good deal of awareness preventing campaigns, hypertension is a major challenge worldwide [8].

There are many factors that influence the maintenance of high blood pressure: the patient's socio-demographic characteristics (gender, age, education, marital status, employment), clinical factors of the disease (number of visits to their GP, duration of illness, comorbidities), class, number, dosage and cost of antihypertensives as well as patient knowledge about hypertension, its prevention and treatment. A common cause of hypertension treatment failure is inadequate patient knowledge about the disease and the importance of proper use of prescribed therapy, which is essential for maintaining adequate blood pressure [9].

\section{AIM}

The aim of this study was to investigate the influence of knowledge about hypertension and associated factors in controlling high blood pressure levels among hypertensive outpatients in the municipality of Bačka Topola, Republic of Serbia.

\section{METHODS}

This academic, qualitative phase IV study using questionnaire as a research instrument, was approved by the Ethics Committee (EC) of the Faculty of Medicine in Novi Sad (EC Approval $\mathrm{N}^{\circ}$ 01-39/2/1) and the Ethics Committee of the Primary Health Care Center „Dr Hadži Janoš” in Bačka Topola (EC Approval $\mathrm{N}^{\circ}$ 01-1493). The questionnaire was designed for this study by the principal investigator and approved by the EC, too. All patients were required to sign Informed Consent for participating in the study.

The study was conducted in Bačka Topola municipality (which includes 23 local communities), with 33.321 inhabitants (according to the 2011 Census). The study sample included adult patients with essential hypertension (based on an International Statistical Classification of Diseases, $10^{\text {th }}$ Revision code I10: Hypertensio arterialis essentialis (primaria)) who consulted general practitioners at Primary Health Care Centre in Bačka Topola between March 20, 2019 and March 29, 2019. [10]. After giving their written informed consent, they were instructed by the researchers on how to complete the questionnaire. Patients who visited these Primary Health Care Centres in Bačka Topola several times filled in the questionnaire only once. The age of patients was $\geq 30$ and they had been diagnosed with essential hypertension for at least 6 months prior to study. Patients who had secondary hypertension, pregnant women, and those with acute diseases during the survey period were 
excluded from the study.

The total number of questionnaires which were distributed among the patients in three Primary Health Care Centres in Bačka Topola of the above mentioned institute was 100. Out of these, 24 questionnaires were rejected, 14 were filled incorrectly and 62 were filled completely.

The questionnaire consisted of three separate parts. Firstly, it contained questions providing information about the patients' socio-demographic characteristics. Secondly, our goal was to collect medication related factors such as: how many antihypertensive drugs were needed for lowering their tension, how many medications and how many doses daily did they take, which antihypertensives did they use, how often did they visit their doctor in the previous year to check their hypertension and whether they were paying copayment for antihypertensive drugs. Finally, we would assess the subjects' knowledge about hypertension. Knowledge about hypertension was assessed on a 15-point scale, based on answers to 15 questions. The scale was adapted from the one used in a similar study in Cameroon to assess knowledge about hypertension [11]. A score $<8$ represented poor knowledge, a score from 9-12 represented average knowledge, and a score from 13-15 represented adequate knowledge.

Blood pressure was measured twice on the same arm after the participant had rested for $5 \mathrm{~min}$, and the average of both values was considered the blood pressure of the participant. Blood pressure $\leq 140 / 90 \mathrm{mmHg}$ represented well controlled, and blood pressure $\geq 140 / 90 \mathrm{mmHg}$ represented poorly controlled blood pressure.

The data collected from the questionnaires were statistically processed in Microsoft Excel 2007. Results are shown as mean velues and in proportion.

\section{RESULTS}

\section{Patients' socioeconomic and clinical charac- teristics}

The following patients' sociodemographic and medication related characteristics were recorded: The average age was $62.9 \pm 10.7$ years and $58.1 \%$ of the respondents were female. The highest level of education for majority of respondents was primary school (51\%), and almost three-quarters $(71 \%)$ were married. Majority of the participants were retired (58\%). With regard to the duration of hypertension treatment $(32.3 \%)$ the majority were taking antihypertensives between 5 and $<9$ years. Less than half of patients (43.5\%) were paying copayment for their medications. Approximately a third of patients (33.8\%) were on the therapy with two antihypertensives, and more than half of patients (63.9\%) were taking it twice a day.

The majority of subjects in the study used ACE inhibitors (80.8\%) followed by beta blocking agents $(46.8 \%)$, calcium channel blockers $(22.6 \%)$, the combination of ACE inhibitor and diuretic (22.6\%) and only diuretics (21\%). Fixed combinations of antyhipertensives (ACE inhibitors + diuretic + calcium channel blocking agents) received
Figure 1. Frequency distribution of the main groups of antihypertensive drugs among outpatients with essential hypertension

ACEi-angiotensin-converting enzyme inhibitors;

BBs- beta blocking agents;

CCBs-calcium channel blockers; FD1- fixed dosed of antihypertensive (ACEi+Ds);

Ds- diuretics;

ARBs- Angiotensin II receptors antagonists;

FD2- fixed dosed of antihypertensive $(\mathrm{ACEi}+\mathrm{Ds}+\mathrm{CCB})$;

Sy-alpha-2 adrenergic receptor agonist.

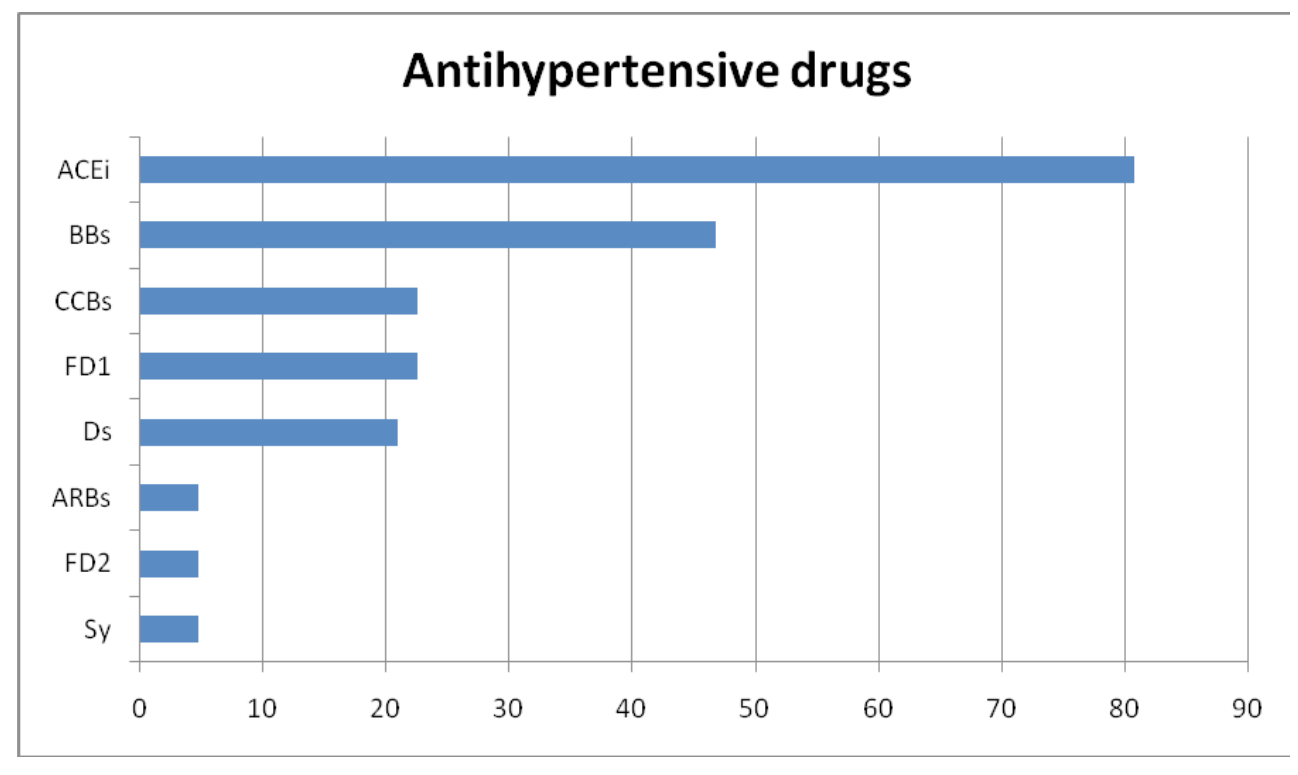




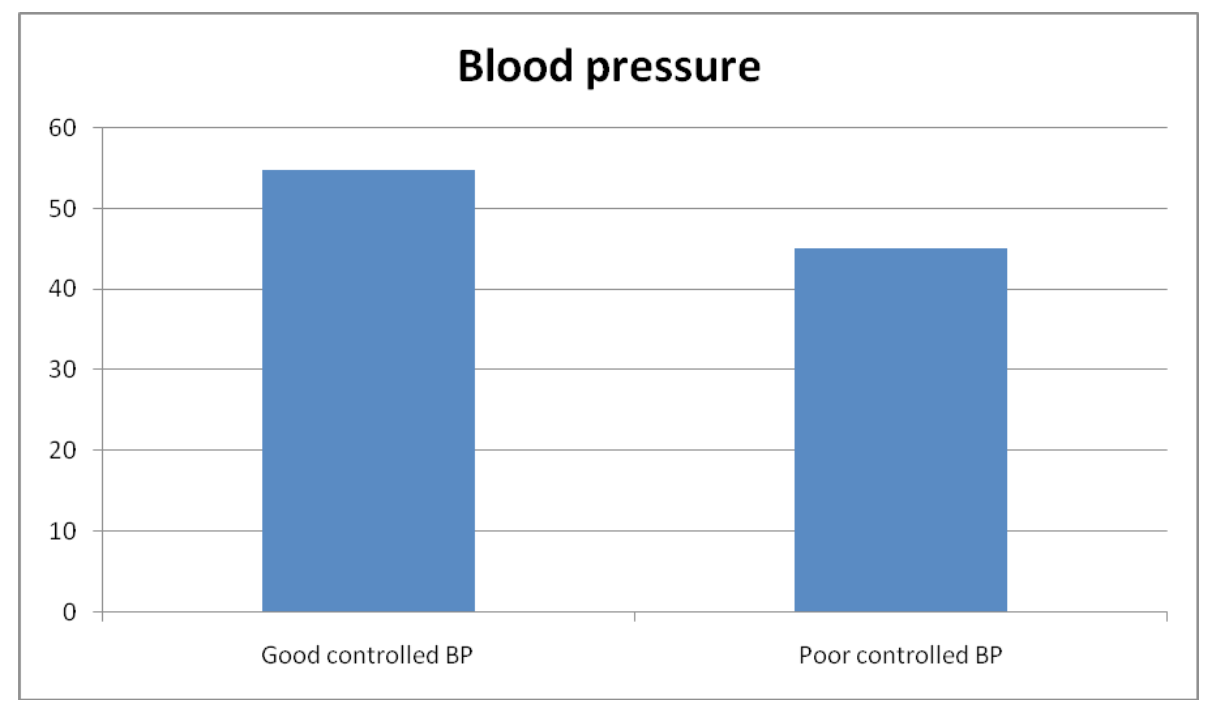

$4.8 \%$ of patients, alpha- 2 adrenergic receptor agonist (methyldopa) $4.8 \%$, and angiotensin II receptor antagonists $4.8 \%$. Enalapril and ramipril were the most frequently prescribed antyhipertensives among ACE inhibitors, with amlodipine and nifedipine among the calcium channel blockers (Fig.1).

\section{Blood pressure control}

Regarding the blood pressure control, more than half of participant in the study had well controlled blood pressure (54.8\%), whereas $45.2 \%$ had poorly controlled blood pressure
(Fig. 2).

We compared the patients' sociodemographic factors in relation to the blood pressure control (Table 1). The contribution of participants younger than 60-69 years was higher in the group with good blood pressure control as well as participants with a university degree and secondary school compared to the contribution of participants in the group with poor blood pressure control.

We compared the patients' sociodemographic factors in relation to the blood pressure control (Table 1). The contribution of participants younger than 60-69 years was
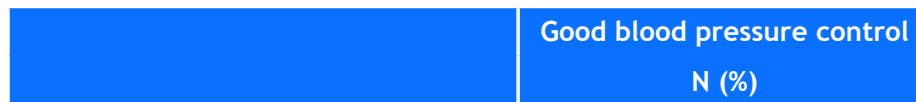

Age:

$80-89$

70-79

60-69

50-59

40-49

30-39

Gender:

Male

Female

Marital status:

Married

Single

Widowed/Divorced

Educational status:

Primary

Secundary

Tertiary

Employment status:

Employed

Unemployed

Retired

\section{Poor blood pressure control \\ N (\%)}

$2(5.5)$
$9(25.5)$
$12(34.2)$
$7(20)$
$4(12)$
$1(2.8)$

20 (57)

15 (43)

$25(71.5)$

$3(8.5)$

7 (20)

12 (34)

19 (54)

4 (12)

$9(20)$
$7(20)$
$19(54)$
Figure 2. The distribution of the frequency of patients according to the levels of blood pressure (BP) in the study groups of patients
Table 1. Comparison of patients' sociodemographic factors in relation to the blood pressure control 
Table 2. Comparison of patients' medication related factors in relation toto the blood pressure control
Table 3. Patients' sociodemographic factors in relation to a knowledge about hypertension

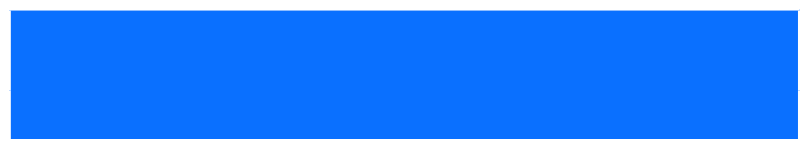

Good blood
pressure control
N (\%)

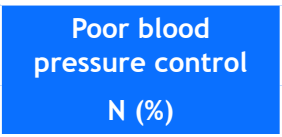

How many times did you visit your GP to check your blood pressure?

Not once

$1-2$

3-5

More than 6

I'm not going, I have a blood pressure monitor at home

$3(8.5)$

$2(5.7)$

$11(31.4)$

7 (20)

$12(34.2)$

2 (7.3)

$6(22.2)$

3 (11.1)

$6(22.2)$

How many years have you been taking antihypertensive drugs?

Less than 5 years

$12(34.2)$

$11(31.4)$

$5(14.2)$

10-14 years

More than 15 years

7 (20)

$3(11)$

$12(44.4)$

$6(22.2)$

$6(22.2)$

How many medications do you use?

One

Two

Three

More then four

$12(34.2)$

$12(34.2)$

8 (22.9)

3 (8.7)

6 (22.2)

10 (37)

$11(40.8)$

How many daily do you take it?

Once

Twice

Three times

Four times or more

$9(26)$
$21(60)$
$4(12)$
$1(2)$

4 (14.9)

20 (74)

3 (11.1)

0

Do you have to pay copayment for antihypertensive drugs?

Yes

$25(71.5)$

10 (28.5)

$10(37)$

No

$14(40)$

17 (63)

Are you taking antidiabetic drugs?

Yes

$21(60)$

13 (48.1)

No

$14(51.9)$

Are you taking hypolipemic drugs?

Yes

17 (49)

8 (29.7)

No

$18(51)$

$19(70.3)$

higher in the group with good blood pressure control as well as participants with a university degree and secondary school compared to the contribution of participants in the group with poor blood pressure control.

We compared the patients' medica-

\begin{tabular}{|c|c|c|c|}
\hline & $\begin{array}{c}\text { Adequate } \\
\text { N (\%) }\end{array}$ & $\begin{array}{c}\text { Average } \\
\text { N (\%) }\end{array}$ & $\begin{array}{l}\text { Poor } \\
\text { N (\%) }\end{array}$ \\
\hline $\begin{array}{l}\text { Age: } \\
80-89 \\
70-79 \\
60-69 \\
50-59 \\
40-49 \\
30-39\end{array}$ & $\begin{array}{c}1(4.4) \\
4(17.4) \\
7(30.4) \\
7(30.4) \\
4(17.4) \\
0\end{array}$ & $\begin{array}{c}2(5,7) \\
12(34,3) \\
12(34,3) \\
6(17,2) \\
2(5,7) \\
1(2,8)\end{array}$ & $\begin{array}{c}1(25) \\
0 \\
2(50) \\
1(25) \\
0 \\
0\end{array}$ \\
\hline $\begin{array}{l}\text { Gender: } \\
\text { Male } \\
\text { Female }\end{array}$ & $\begin{array}{l}13(56.6) \\
10(43.4)\end{array}$ & $\begin{array}{l}11(31) \\
24(69)\end{array}$ & $\begin{array}{l}2(50) \\
2(50)\end{array}$ \\
\hline $\begin{array}{l}\text { Educational status: } \\
\text { Primary } \\
\text { Secondary } \\
\text { Tertiary }\end{array}$ & $\begin{array}{c}7(30.4) \\
13(60) \\
3(8.6)\end{array}$ & $\begin{array}{c}22(63) \\
12(34,2) \\
1(2,8)\end{array}$ & $\begin{array}{c}4(100) \\
0 \\
0\end{array}$ \\
\hline $\begin{array}{l}\text { Employment status: } \\
\text { Employed } \\
\text { Unemployed } \\
\text { Retired }\end{array}$ & $\begin{array}{c}8(34.8) \\
3(13) \\
12(52.2)\end{array}$ & $\begin{array}{c}4(12) \\
9(26) \\
22(62)\end{array}$ & $\begin{array}{l}1(25) \\
1(25) \\
2(50)\end{array}$ \\
\hline
\end{tabular}




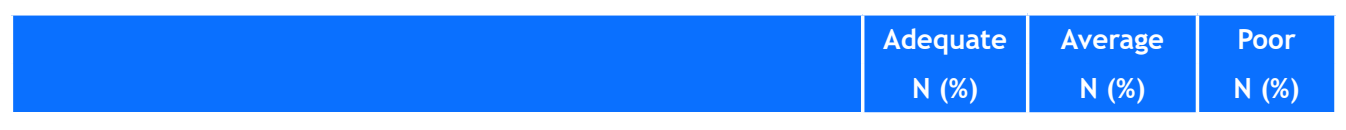

How many times did you visit your GP to check your blood pressure?

Not once

$1-2$

3-5

More than 6

I'm not going, I have a blood pressure monitor at home

How many years have you been taking antihypertensive drugs?

Less than 5 years

$5-9$ years

10-14 years

More than 15 years

How many medications do you use?

One

Two

Three

More then four

How many daily do you take it?

Once

Twice

Three times

Four times or more

Do you have to pay copayment for antihypertensive drugs?

Yes

No

Are you taking antidiabetic drugs?

Yes

No

Are you taking hypolipemic drugs?

Yes

No

\begin{tabular}{|c|c|c|}
\hline $19(82.6)$ & $15(43)$ & $1(25)$ \\
\hline $4(17.4)$ & $20(57)$ & $3(75)$ \\
\hline $8(34.8)$ & $16(45.7)$ & $3(75)$ \\
\hline $15(65.2)$ & $19(54.3)$ & $1(25)$ \\
\hline $9(39.1)$ & $13(37.1)$ & $1(25)$ \\
\hline $14(60.9)$ & $22(62.9)$ & $3(75)$
\end{tabular}

tion related factors in relation to the blood pressure control. The share of participants who visited their GP more frequently, who were taking antihypertensives for less then five years, who received one or two antihypertensives, subjects who were paying copayment for antihypertensive drugs and who were not taking antidiabetic drugs was higher in the group with good blood pressure control compared to the group with poor blood pressure control.

\section{Knowledge of hypertension}

We compared the patients' socio-demographic factors in relation toto the adequate knowledge about hypertension (Table 3). Male participants had adequate knowledge in higher percentage than female ( $56.6 \%$ vs. $43.4 \%)$. Based on education level and employment subjects with a degree as well as employed patients had more frequently adequate knowledge compared to the patients in the group with average or poor knowledge.

In this study, the patients' medication related factors were compared with the adequate knowledge about hypertension (Table 4). The share of participants who were more frequently visited their GP, who were taking antihypertensives less then five years, and who used two antihypertensives more frequently
Table 4. Comparison of patients' medication related factors in relation to a knowledge about hypertension

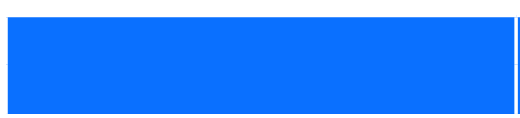

Good blood pressure control

$$
\text { N (\%) }
$$

Adequate knowledge

21 (91.4)

Average knowledge

13 (37.1)

1 (25)
Poor blood pressure control

\section{$\mathrm{N}(\%)$}

2 (8.6)

$22(62.8)$

$3(75)$
Table 5. Relationship between subjects' blood pressure and knowledge level 
had adequate knowledge. Patients who were paying copayment for antihypertensive drugs and those who were not taking antidiabetic and hypolipemic drugs more frequently had appropriate level of knowledge about hypertension.

\section{Blood pressure control with knowledge about hypertension}

Subjects' blood pressure control showed the following relationship with the knowledge about hypertension. Out of 64 participants $37 \%$ had adequate knowledge about hypertension, 56.4\% had average knowledge, and $6.6 \%$ had poor knowledge. The majority of subjects with adequate knowledge had good blood pressure control (91.4\%), while only $37.1 \%$ of subjects with average knowledge had good blood pressure control. Among the patients with poor knowledge, $3 / 4$ have poor blood pressure control (Table 5).

Table 6. describes the comparison between theknowledge about hypertension with the blood pressure value. The majority of patients from both groups were familiar with the safe level of blood pressure, whereas statements related to disease treatment and adequate lifestyle were different between the group with good blood pressure control compared to the group with poor blood pressure control. More than $2 / 3$ of all subjects from both groups responded correctly that smoking increases the likelihood of hypertension and that regular exercise reduces the likelihood of hypertension, although the percentage was higher in the group of patients with good controlled blood pressure. More than half of the subjects $(57.1 \%)$ from the group with good blood pressure control reported that eating more salt has no effect on blood pressure as well as that medication alone can control hypertension (Table 6).

\section{DISCUSSION}

In our study conducted in the municipality in Bačka Topola, the percentage of female was approximately the same to that reported in the last Serbian census conducted in 2011. These results are similar to those in a US study with the average age in the study population was of 58.9 , and $52.2 \%$ of subjects were also female [12].

\begin{tabular}{|c|c|c|c|c|}
\hline & \multicolumn{2}{|c|}{$\begin{array}{l}\text { Good blood } \\
\text { pressure control }\end{array}$} & \multicolumn{2}{|c|}{$\begin{array}{l}\text { Poor blood } \\
\text { pressure control }\end{array}$} \\
\hline & $T / F$ & $\%$ & $T / F$ & $\%$ \\
\hline 1. Normal blood pressure value is $120 / 80 \mathrm{mmHg}$ & $34 / 1$ & 97.1 & $24 / 3$ & 88.8 \\
\hline $\begin{array}{l}\text { 2. Blood pressure higher than } 140 / 90 \mathrm{mmHg} \text { is called } \\
\text { hypertension }\end{array}$ & $32 / 3$ & 91.4 & $23 / 4$ & 85.1 \\
\hline 3. The risk for hypertension is increasing with age & $22 / 13$ & 62.8 & $13 / 14$ & 48.1 \\
\hline $\begin{array}{l}\text { 4. Both men and women have equal chances of developing } \\
\text { hypertension }\end{array}$ & $33 / 2$ & 94.2 & $17 / 10$ & 62.9 \\
\hline $\begin{array}{l}\text { 5. Symptoms of high blood pressure areheadache, } \\
\text { dizziness and fatigue }\end{array}$ & $33 / 2$ & 94.2 & $19 / 8$ & 70.3 \\
\hline 6. Hypertension is curable condition & $28 / 7$ & 80 & $20 / 7$ & 74 \\
\hline 7. The development of hypertension can be hereditary & $27 / 8$ & 77.1 & $15 / 12$ & 55.5 \\
\hline $\begin{array}{l}\text { 8. Smoking increases the chances of developing hyperten- } \\
\text { sion }\end{array}$ & $29 / 6$ & 82.8 & $19 / 8$ & 70.3 \\
\hline $\begin{array}{l}\text { 9. Eating fatty foods increases the chances of developing } \\
\text { hypertension }\end{array}$ & $35 / 0$ & 100 & $24 / 3$ & 88.8 \\
\hline $\begin{array}{l}\text { 10. Being overweight increases the chances of developing } \\
\text { hypertension }\end{array}$ & $33 / 2$ & 94.2 & $25 / 2$ & 92.5 \\
\hline $\begin{array}{l}\text { 11. Regular physical activity reduces risk of developing } \\
\text { hypertension }\end{array}$ & $29 / 6$ & 82.8 & $21 / 6$ & 77.7 \\
\hline 12. Eating more salt has no effect on blood pressure & 20/15 & 57.1 & $12 / 15$ & 44.4 \\
\hline 13. Red meat is good for control of hypertension & $25 / 10$ & 71.4 & $11 / 6$ & 40.7 \\
\hline 14. Medication alone can control hypertension & $20 / 15$ & 57.1 & $6 / 21$ & 22.2 \\
\hline $\begin{array}{l}\text { 15. Hypertension can lead to other life-threatening } \\
\text { diseases }\end{array}$ & $31 / 4$ & 88.5 & $25 / 2$ & 92.5 \\
\hline
\end{tabular}

Table 6. Knowledge about subjects about hypertension depending on blood pressure

T/F: true/false and percentages denote those who said "True" 
Despite neither of the main types of antihypertensives being favored in Serbian guideline for hypertension management, ACE inhibitors were the most commonly prescribed antihypertensivesin the Municipality in Bačka Topola, which are also the most commonly used antihypertensive agents in Serbia [13]. $ß$-receptor blockers were the second most frequently prescribed drugs, with bisoprolol, nebivolol and metoprolol the most commonly used. Selective bisoporolol is used as a ß-receptor blocker among younger patients with hypertension. The use of $\beta$-receptor blockers decreases in the elderly, whereas diuretics are the typical representatives in this age group. Likewise, according to the RIACE multicenter study conducted in Italy, $69.3 \%$ of participants with hypertension were treated with $\mathrm{ACE}$ inhibitors, followed by $\beta$-receptor blockers $(10.3 \%)$ and calcium channel blockers (9.1\%) [14].

Multiple studies emphasized that ramipril, the most commonly used ACE inhibitor, had been shown to reduce myocardial infarction, stroke and death [15]. On the other hand, amlodipine was a frequent choice in the elderly patients [16], whereas in our study nifedipine was most commonly used by patients in a delayed release form [17]. Fixed combinations of antihypertensives (ACEs with diuretics) allow combination therapy with a higher patient compliance and thus better control of hypertension compared to multiple drugs administration. However, in Serbia, a fixed combination of antihypertensives can be reimbursed only after a failure to achieve blood pressure control with a 3-month combination therapy with single drug preparation and it has a high share of copayment [17].

In our study, $54.8 \%$ of subjects had adequate control of blood pressure, and those aged 50-59 years and younger had better control of blood pressure than older subjects. Similarly, in the study conducted in the Sumadija region, $46 \%$ subjects had good control of blood pressure [18]. These results are in contrast to the study related to prevalence of arterial hypertension in Serbia, according to which only $27 \%$ of subjects maintained their blood pressure within the optimal values [19]. In the survey performed in the USA, patients with hypertension between ages of 40-49 and those aged 50-59 had good control of blood pressure, while less adequate management of hypertension was recorded in people aged 70-
79 and over 80 years [20].

A survey in Uzbekistan has shown that better management of the disease can be achieved by improving access to finance, affordability and access to medicines [21]. In our study, $71.5 \%$ of patients paying copayment for their antihypertensive drugs had well controlled blood pressure, while $63 \%$ of those who did not pay for their medication had poorly controlled blood pressure. The question arises whether patients take the medicines as prescribed. CARDIA study by Matthews et. al examined the onset of hypertension over a 10-year period and they showed that income decline affected the occurence of hypertension [22].

The results of the study showed that patients who did not have diabetes mellitus in addition to hypertension and who did not take antidiabetic drugs had better controlled blood pressure comparing to those who were also taking these medications in addition to antihypertensive agents.

In our study, $38.7 \%$ of the patients used medication for the treatment of elevated cholesterol and triglyceride levels, besides antihypertensive drugs. This high rate obtained in the research can be explained by the older age of study sample [23].

In Canada, similar results were obtained, with $48.8 \%$ of subjects taking lipidlowering drugs [24]. Cordero et.al recorded no association between elevated lipid levels and blood pressure [24].

Out of the socio-demographic factors, and education influenced the knowledge about hypertension and its treatment. Subjects with a higher level of education achieved a higher level of knowledge, and their blood pressure was at an appropriate level. The association between higher education and blood pressure as well as the appropriate knowledge about hypertension has been reported in other studies $[20,25,26]$.

Subjects with adequate knowledge about hypertension had good control of blood pressure in higher percentage than those with average knowledge. Similar results were found in survey conducted in Cameroon [11] as well as in one from India [27]. A study performed among patients with hypertension in Turkey recorded that the presence of hypertension motivates patients to learn more about their disease and how to treat it. Namely, participants had the best level of knowledge about hypertension as a disease, while they lacked 
knowledge about disease management and lifestyle. Similar research conducted in Poland showed the same result [9].

In a study from Pakistan, patients who had adequate knowledge about hypertension also had adequate blood pressure control, whereas in Congo, patients who did not have adequate knowledge about hypertension did not feel the need to regularly take the prescribed therapy $[28,29]$.

Subjects in our study had poor knowledge related to hypertension risk factors and consequences (smoking, excessive salt intake, and use of red meat). These results suggest that it is very important to educate patients about giving up harmful habits and the benefits of a healthy lifestyle in order to actively maintain their health or reduce the occurrence of complications. In accordance with the results of our study, favorable outcome expectation, positive attitudes, and appropriate practices for hypertension and relevant healthy lifestyles were found in smaller proportions of participants in the study conducted among hypertensive persons in Seychelles [30].

\section{CONCLUSION}

In conclusion, $45.2 \%$ of the patients had poorly controlled blood pressure and the majority were treated with ACE inhibitors (80.8\%) followed by beta blocking agents (46.8\%), and calcium channel blockers (22,6\%). Majority of subjects with adequate knowledge had good blood pressure control (91.4\%), while only $37.1 \%$ of subjects with average knowledge had good blood pressure control. Special attention should be given to factors most associated with poor blood pressure control and lower level of knowledge about hypertension - older age, female gender, lower level of education, less frequent visits to the General Practitioner, patients taking more than one antihypertensive drug, patients with longer duration of hypertension treatment and patients who were not paying copayment for their antihypertensives. Therefore, education campaign should be focused on hypertensive patients with these sociodemographic and medication related characteristics. This study specifies potential areas of hypertension education in relation to healthy lifestyle that could be improved by patients' knowledge about hypertension. Further research that thoroughly assesses a wide range of potential influences, including patients' be- liefs about their disease and medications may help primary care providers better understand and improve medication-taking behaviors as well as patients' knowledge about hypertension.

\section{STUDY LIMITATIONS}

There are also some limitations to our study. The study enrolled only subjects from primary health centers, thus the data cannot reflect the condition of hypertensive subjects addmited to secondary or tertiary health centers. Also, the sample size may be relatively small, but these findings give an indication of what is happening in a single municipality. A validated questionnaire adapted from earlier study was used to assess knowledge about hypertension (third part of questionnaire) [11]. Professional translator was involved in translation and back-translation Necessary modifications were made to enable correct answers to questions and statements. The content, comprehension, readability and design of the questionnaire were pre-tested on 15 adult subjects in Bačka Topola municipality. Out of 100 questionnaires distributed, the survey was rejected and/or was not filled correctly by one third of participants. This low response rate could be explained by the fact that it is possible that people who were more informed or interested in the topic were more willing to participate. Furthermore, limited time to recruit respondents was also a drawback. Therefore, a larger-scale study is needed where larger population of patients would define further scope of knowledge about hypertension and associated factors among patients with hypertension in Serbia.

\section{ACKNOWLEDGEMENTS}

This study was supported by the Ministry of Science and Technological Development, Republic of Serbia (project No.41012) and the Provincial Secretariat for Science and Technological Development, Autonomous Province of Vojvodina [grant number 142-4512565/2019-02].

\section{CONFLICTS OF INTEREST}

All authors declare no conflict of interest. 


\section{REFERENCES}

1. Mancia G, Fagard R, Narkiewicz $K$, Redon J, Zanchetti A, Bohm M, et al. ESH/ESC Guidelines for the management of arterial hypertension: The Task force for the management of arterial hypertension of the European Society of Hypertension (ESH) and of the European Society of Cardiology (ESC). J Hypertens. 2013;31(7): 1281-357.

2. Ministry of Health of the Republic of Serbia and Institute of Public Health of Serbia "Dr Milan Jovanović Batut" Final Report and Basic Results of the 2006 Health Survey of the Republic of Serbia. Beograd. 2007: 56-848.

3. Ministry of Health of the Republic of Serbia and Institute of Public Health of Serbia "Dr Milan Jovanović Batut". Results of the 2013 Population Health Survey of Serbia. Beograd. 2014: 24-96.

4. Ministry of Health of the Republic of Serbia and Institute of Public Health of Serbia "Dr Milan Jovanović Batut".Final Report and Basic Results of the 2016 Health Survey of the Republic of Serbia. Beograd. 2017: 417-37.

5. Petrović V.:Health status of the population of AP Vojvodina 2016. Institute of Public Health of Vojvodina. [Internet]. 2017. Available from: http://www. izjzv.org.rs $/$ ?ng=lat\&cir=0\&link=4-21

6. World Health Organization. World Health Statistics 2012. Geneva: WHO; [Internet], 2012. Available from: http://apps.who.int/iris/bitstream/10665/44844/1/9789241564441_eng.pdf.

7. WHO. The Pursuit of Responsible Use of Medicines: Sharing and Learning from Country Experiences Technical Report prepared for the Ministers Summit on The benefits of responsible use of medicines: Setting policies for better and cost-effective health care. WHO. 2012; Available from: http:// apps.who.int/iris/bitstream/10665/75828/1/ WHO_EM P_MAR_2012.3_eng.pdf

8. Perkovic V, Huxley R, Wu Y, Prabhakaran D, MacMahon $\mathrm{S}$. The burden of blood pressure-related disease: a neglected priority for global health. Hypertension. 2007;50(6):991-7.

9. Jankowska-PolańskaB, Uchmanowicz I, Dudek K, Mazur G. Relationship between patients' knowledge and medication adherence among patients with hypertension. Patient Preference and Adherence 2016;(10): 2437-47.

10. World Health Organization. ICD-10: International Statistical Classification of Diseases and Related Health Problems: tenth revision, $2^{\text {nd }}$ ed. World Health Organization. 2010. Available from: https://www. who.int/classifications/icd/ICD10Volume2_en_2010.pdf

11. Akoko BM, Fon PN, Ngu RC, Ngu KB. Knowledge about Hypertension and Compliance with Therapy Among Hypertensive Patients in the Bamenda Health District of Cameroon: A Cross-sectional Study. Cardiol Ther. 2017;(6): 53-67.
12. Egan BM, Zhao Y, Axon RN. US trends in prevalence, awareness, treatment, and control of hypertension, 1988-2008. JAMA. 2010;303(20):2043-50.

13. Šipetić T. Turnover and consumption of finished drugs for human use in the Republic of Serbia in 2010. Agency for Medicines and Medical Devices of Serbia. Beograd; 2011.

14. Penno G. Solini A, Bonora E, Fondelli C, Orsi $E$, Zerbini $G$, et al. Gender differences in cardiovascular disease risk factors, treatments and complications in patients with type 2 diabetes: the RIACE Italian multicentre study. J Intern Med. 2013;274(2):176-91.

15. Yusuf S, Sleight P, Pogue J, Bosch J, Davies $R$, Dagenais $G$. Effects of an angiotensin-converting-enzyme inhibitor, ramipril, on cardiovascular events in high-risk patients. The Heart Outcomes Pre vention Evaluation Study Investigators. N Engl J Med. 2000 Jan 20;342(3):145-53.

16. Kažić T. Ostojić M. Cardiovascular drugs: a manual for therapy. Beograd : Integra; 2011. p.18-43

17. Snider M. Nuzum, D.Veverka A. Long-acting nifedipine in the management of the hypertensive patient. Vasc Health Risk Manag. 2008 December; 4(6): 1249-1257

18. Marinović M, Ilić N, Đokić D, Andrejević V, Damjanović G, Samardžić G, et al. Prevalenca hipertenzije kod odraslih u Šumadiji - unakrsno istraživanje. Vojnosanit Pregl. 2014;71(3):245-50.

19. Lovic D, Stojanov V, Jakovljevic B, Krotin M, Jurišić V, Dorđević D, et al. Prevalence of arterial hypertension in Serbia: PAHIS study. J hypertens. 2013;31(11):2151-7.

20. Borzecki AM, Glickman ME, Kader B, Berlowitz DR. The Effect of Age on Hypertension Control and Management. Am J Hypertens. 2006;19(5):520-7.

21. Malik A, Yoshida Y, Erkin T, Salim D, Hamajima $\mathrm{N}$. Hypertension-related knowledge, practice and drug adherence amond in patients of a hospitam in Samarkand, Uzbekistan.Nagoya J. Med. Sci. 2014;(76): 255-63.

22. Spruill TM. Chronic Psychosocial Stress and Hypertension. CurrHypertens Rep. 2010;12(1):10-6.

23. Belletti DA, Zacker C, Wogen J. Effect of cardiometabolic risk factors on hypertension management: a cross-sectional study among 28 physician practices in the United States. CardiovascDiabetol. 2010;9:7.

24. McAlister FA, Wilkins $\mathrm{K}$, Joffres $M$, Leenen $\mathrm{FHH}$, Fodor $\mathrm{G}$, Gee $\mathrm{M}$, et al. Changes in the rates of awareness, treatment and control of hypertension in Canada over the past two decades. CMAJ. 2011;183(9):1007-13.

25. Pérez MCR, de León AC, Torres RMM, Coello SD, Sánchez JJA, Díaz BB, et al. Factors Associated With Knowledge and Control of Arterial Hyperten- 
sion in the Canary Islands Rev EspCardiol (Engl Ed). 2012;65(3):234-40.

26. Dhungana RR, Pandey AR, Bista B, Joshi S, Devkota S. Research Article Prevalence and Associated Factors of Hypertension: A Community-Based Cross-Sectional Study in Municipalities of Kathmandu, Nepal. International Journal of Hypertension Volume 2016 (2016).

27. Susan R, Anu K, Achu T, Soumya G, Vijayakumar $\mathrm{K}$, Anish T. Antihypertensive drug compliance acrossclinic and community settings, in Thiruvananthapuram, South India. Health Sci. 2012;1(3):JS002A.

28. Saleem F, Hassali MA, Shafie AA, Awad AG, Bashir S. Association between Knowledge and Drug Adherence in Patients with Hypertension in Quetta, Pakistan. Tropical J Pharm Res. 2011;10(2): 125-32.

29. Lulebo AM, Mutombo PB, Mapatano MA, Mafuta EM, Kayembe PK, Ntumba LT et al. Predictors of non-adherence to antihypertensive medication in Kinshasa, Democratic Republic of Congo: a crosssectional study. BMC Res Notes 2015;(8): 526.

30. Aubert L, Bovet P, Gervasoni JP, Rwebogora A, Waeber B, Paccaud F. Knowledge, attitudes, and practices on hypertension in a country in epidemiological transition. Hypertension. 1998;31(5):113645. 


\section{Uticaj znanja pacijenata o hipertenziji na kontrolu krvnog pritiska - u kvalitativnoj studiji}

Tinde I. Halgato ${ }^{1}$, Dora K. Kaloci ${ }^{1}$, Roland N. Grujić ${ }^{1}$, Sabolč J. Mora ${ }^{1}$, Ana D. Tomas ${ }^{2}$, Milica M. Paut Kusturica ${ }^{2}$, Olga J. Horvat ${ }^{2}$

${ }^{1}$ Dom zdravlja “Dr Janoš Hadži” Bačka Topola, Srbija

${ }^{2}$ Katedra za farmakologiju i toksikologiju, Medicinski fakultet, Univerzitet u Novom Sadu, Novi Sad, Srbija

\section{KRATAK SADRŽAJ}

Uvod: Hipertenzija je značajan faktor rizika za nastanak cerebrovaskularnog insulta i akutnog infarkta miokarda. Održavanje krvnog pritiska na odgovarajućem nivou pomaže u sprečavanju nastanka komplikacije.

Cilj: Cilj ove studije je bio da se ispita uticaj znanje o hipertenziji i pratećih faktora na kontrolu krvnog pritiska kod vanbolničkih pacijenata sa hipertenzijom u opštini Bačka Topola, Republika Srbija.

Metod: Studija je sprovedena u martu 2019. godine u službama opšte medicine Doma Zdravlja u opštini BačkaTopola, među pacijentima koji su posetili svog lekara i popunili anonimni upitnik. Upitnik je obuhvatao pitanja o socio-demografskim karakteristikama, o faktorima vezanih za antihipertenzivne lekove, kao i o znanju o hipertenziji. Rezultati: Prosečnastarost ispitanika je bila $62.9 \pm 10.7$ godina. Najčešće propisivani antihipertenzivni lekovi bili su ACE inhibitori $80,8 \%$, zatim B-blokatori $46.8 \%$, blokatori kalcijumskih kanala $22.6 \%$, diuretici $21 \%$, a fiksna kombinacija antihipertenziva korišćena je kod $4.8 \%$ pacijenata. Većina ispitanika sa adekvatnom znanjem imala je dobro kontrolisan krvni pritisak (91.4\%), dok samo $37.1 \%$ ispitanika sa prosečnom znanjem je imala dobro kontrolisan krvni pritisak. Ostali faktori koji su najčešće povezani sa lošom kontrolom krvnog pritiska i znanja nižeg nivoa o hipertenziji bili su: starija starosna dob, ženski pol, niži stepen obrazovanja, ređa poseta izabranog lekara, pacijenti sa više od jednog antihipertenzivnog leka, pacijenti sa dužim trajanjem lečenja hipertenzije i pacijenti koji nisu imali doplatu na antihipertenzivne lekove. Zaključak: Rezultati studije ukazuju da znanje pacijenata o hipertenziji i pratećih faktora u vezi sa lečenjem hipertenzije ima važnu ulogu na održavanju krvnog pritiska na adekvatnom nivou. Stoga edukacija ima ključnu ulogu na utemeljivanju racionalne upotrebe antihipertenziva i lečenja hipertenzije.

Ključne reči: antihipertenzivna terapija, znanje o antihipertenzivnoj terapiji, antihipertenzivni lekovi 